\title{
Lietuvos upių ekologinio nuotėkio vertinimas
}

Brunonas Gailiušis ${ }^{1}$,

Gintaras Adžgauskas ${ }^{1}$

Aldona Tomkevičiene $\dot{e}^{1}$,

Diana Meilutytè-Lukauskiené $\dot{e}^{1,2}$

${ }^{1}$ Lietuvos energetikos institutas,

Breslaujos g. 3, 44403 Kaunas

El.paštas Brunonas.Gailiusis@lei.lt

${ }^{2}$ Lietuvos sveikatos mokslu universitetas,

A. Mickevičiaus g. 9, 44307 Kaunas
Tvenkiniai daro ịtaką reguliuotų upių vandens organizmams, upès nuotèkiui, tvenkinio krantams ir upès vagai, požeminiams vandenims bei kraštovaizdžiui. Šiuo metu galiojantys teisès aktai reglamentuoja gamtosaugos debitą kaip 30 parų minimalaus debito dali. Šis debitas tenkina tik minimalius vandens ekosistemos poreikius ir nepriklauso nuo metų vandeningumo. Tokia gamtosaugos debito apskaičiavimo praktika hidroelektrinèms palieka hidropikingo galimybę.

Straipsnyje aptariami kai kurie Lietuvos mažų ir vidutinių upių tvenkinių eksploatacijos aspektai. Siūloma vietoje gamtosaugos debito reguliuotai upei žemiau tvenkinio nustatyti ekologini nuotékị. Svarbiausia sąlyga apskaičiuojant ekologinị nuotėkị - tvenkinio lygiu ir reguliuotos upès debitų kaitos panašumas su natūralių ežerų ir upių režimu. Nustatyta, kad neištirtų upių prietaka ị tvenkinị ir ekologinis nuotekkis gali būti apskaičiuoti iš atraminių vandens matavimo stočiu duomenų kiekviename 15 Lietuvos upių baseinų. Siekiant reguliuotų upių geros ekologinès būklès, siūloma tobulinti HE turbinas, leidžiančias naudoti upès nuotekkị HE plačiame debitų kaitos intervale, išvengiant pikinio darbo režimo (hidropikingo).

Raktažodžiai: gamtosaugos debitas, ekologinis nuotèkis, reguliuotos upès, tvenkinys, hidropikingas

\section{IVADAS}

Vandens telkiniai naudojami įvairiems tikslams, tačiau ūkinè veikla sukelia padarinius, kurių išvengti neįmanoma. Darnaus vystymosi pagrindinis principas - tenkinti dabartinius visuomenès poreikius nekeliant grèsmès būsimų kartų galimybei tenkinti jų poreikius. Natūralūs ežerai ir upès egzistuoja daugelị metų tokiomis sąlygomis, kai hidromorfologiniai pokyčiai nekelia pavojaus prisitaikiusioms prie šių sąlygų biocenozèms. Tačiau ūkinès veiklos poveikis kai kurioms rūšims kelia didelę išnykimo riziką dèl labai siauro šių rūšių tolerancijos intervalo šiam poveikiui.

Paimti vandenį iš mažos ar vidutinès upès yra įmanoma tik upès slènyje ịrengus tvenkinị. Tvenkinio darbo režimas priklauso nuo tikslų, tačiau viena svarbiausių sąlygų yra upès natūralaus hidrologinio režimo savybių išsaugojimas. Nors kiekvienas tvenkinys turi individualių bruožų, bendri dèsningumai pasireiškia nuotèkio perskirstymu tarp vandeningų ir sausų laikotarpių. Kalbėdami apie ūkinès veiklos būtinumą ir galimybes, privalome analizuoti tvenkinio 
poveikị upių nuotekiui ir vertinti neigiamus padarinius aplinkai.

Reguliuotos upès nuotekis priklauso nuo tvenkinio išteklių valdymo. Negrįžtamas vandens paèmimas, nuotèkio kaupimas tvenkinyje ir jo išleidimas ị žemutinị bjefą, keičiant natūralų hidrologinị upès režimą, yra svarbiausi ūkinès veiklos veiksniai, lemiantys reguliuotos upès ruožo ekologinę būklę. Europos Komisija [1] atkreipè dèmesị i tai, kad siekiant geros ekologinès būklès reguliuotose upese pagrindinè gamtosaugos priemone yra reguliuotos upès ekologinio nuotekio nustatymas, atsižvelgus ị vandens ekosistemos poreikius, išreikštus hidromorfologiniais rodikliais.

Šiuo metu Lietuvoje tvenkinių lygio kaita apribota [2] pagal analogiją su natūraliais ežerais ir lengvai gali būti stebima telemetrijos priemonémis. Absoliučios analogijos tarp natūralaus ežero ir dirbtinio vandens telkinio - tvenkinio - nèra. Tačiau hidroelektrinė yra vandens naudotoja, lemianti upių nuotèkio gamtinio režimo pokyčius ir ekologinio nuotèkio dydį. Siekiant išsaugoti vandens ekosistemas, hidroelektrinių režimas privalo prisitaikyti prie keliamo gamtinio nuotèkio režimo. Hidroelektrinių turbinų įrangos tobulinimas ir reguliuotos upès ekologinio nuotèkio nustatymas yra svarbiausi uždaviniai, kuriems spręsti reikalingi tolimesni tyrimai siekiant, kad pakeisto vandens telkinys būtų geros ekologinès būklès.

Straipsnio tikslas - aptarti Lietuvos mažų ir vidutinių upių ekologinio nuotékio nustatymo galimybes, remiantis sukaupta informacija apie natūralių ir pakeistų vandens telkinių (ežerų ir upių) hidrologinị režimą.

\section{TVENKINIŲ VAIDMUO VANDENS EKOSISTEMOJE}

Tvenkinių poveikis aplinkai nediskutuotinas. Ryškiausiai pastebimi pokyčiai vandens ekosistemoje - kai pastačius užtvanką pažeidžiamas upès vientisumas. Vagoje įrengtas tvenkinys turi kitas negu upe hidromorfologines savybes, nes padideja vandens paviršiaus plotas ir telkinio gylis, sumažèja tèkmès greitis, kyla pavojus tvenkinio krantams [4]. Lietuvos vandens telkinių fauna rūšiu požiūriu negausi, tačiau savita. Jos savitumą lemia didelè vandenų ir jų režimo ịvairovè. Daugiausia rūšių aptinkama upėse, kurių tankis Lietuvoje siekia $1 \mathrm{~km} / \mathrm{km}^{2}[5]$.
Ežeruose ir tvenkiniuose, kurių Lietuvos teritorijoje yra 6 tūkst. [6], fauna skurdesnè negu upèse. Po ledynmečio ežeruose intensyvejjo seklèjimo ir eutrofikacijos procesai, pamažu išnyko šaltamègès žuvys ir kiti vandens gyvūnai. Tik giliausiuose ežeruose dar aptinkamos ledynmečio laikų šaltamègès žuvys (sykai, seliavos) ir vėžiagyviai. Daugelyje ežerų egzistuoja viena ar kelios nelepios žuvų rūšys (karpiai, karosai ar ešeriai), kurios sudaro žuvų bendrijos branduoli.

Vokès upelio ichtiofaunos apžvalga [6] rodo, kad tvenkiniuose didesnè žuvų biomasè, tačiau žemiau užtvankos aptinkama iki 14 rūšių žuvų, kai tvenkinyje pastebètos tik 7 žuvų rūšys. Iprasta, kad tvenkiniuose aptinkama mažiau jautrių taršai vandens organizmų [7]. Tvenkiniuose ypač akivaizdūs vandens bestuburių bendrijos pokyčiai. Pavyzdžiui, upése aptinkamos labai retos ir saugotinos dvigeldžių moliuskų rūšys tvenkiniuose jau nebegyvena. Etaloniniai palyginamieji tyrimai [7], atlikti gretimų nereguliuotų upių vagose, rodo, kad upių tèkmès vientisumo suardymas ir vandeningumo kaitos pokyčiai yra svarbūs ekosistemos būklei.

Užtvankos įrengimas paveikia upès nešmenų režimą, kai tvenkinyje pradedami kaupti nešmenys, kurie dugne sudaro dumblo sluoksni, o žemutiniame bjefe pastebima upès erozija. Kaip parodè tyrimai $[8,9]$, per dešimtmečius trunkanti laikotarpi žemutiniame bjefe susikuria dinaminè vagos procesų pusiausvyra. Pagilejusioje vagoje savigrindos procesai suformuoja dugno substratą, atitinkantị hidrologinio režimo pokyčius. Tuo tarpu tvenkinyje, nusèdus daliai nešmenų, padidejja makrozoobentoso paplitimo erdvé. Dugne paplitę organizmai nuolatos skendi vandenyje ir esant nedideliam vandens lygio svyravimui sukuria palankias sąlygas maitintis ir veistis kai kurių rūšiu žuvims.

Upių vagos ir ežerai susidare per ilgą laikotarpi. Priimant sąlygą, kad svarbiausi vandens telkinių ir jų hidrologinio režimo formavimo veiksniai nuolatiniai, galime kalbèti apie nusistovejusią pusiausvyrą tarp aplinkos ir vandens telkinio [10]. Pakeitę svarbiausius aplinkos fizinius ir geografinius veiksnius, sukuriame naujus paviršinius vandens telkinius, kurie ekosisteminiu požiūriu tampa gyvūnų ir augalų buveinemis, pasižyminčiomis kitomis savybèmis.

İvedus tvenkinių naudojimo ir priežiūros reglamentą [2], pasiektas tvenkinių vandens lygių 
svyravimas per metus analogiškas natūraliems ežerams. Reglamentuotas nuokrypis $\pm 0,1 \mathrm{~m}$ nuo normalaus patvankos lygio garantuoja vandens gyvūnų ir augalijos aplinkos stabilumą, o tvenkinys tampa svarbiu kraštovaizdžio elementu. Tai neabejotinai svarbus ir pažangus žingsnis reguliuojant Lietuvos vandens išteklių naudojimą.

Upių vagų tvenkimas sukuria ịvairiapusę socialinę ir ekonominę naudą. Tačiau yra sričių, kuriose tvenkiniai ne tik keičia tradicinius vandens telkinių naudojimo būdus, bet sukelia nepataisomą žalą. Tai negrižžtamas žemès ūkio naudmenų bei miškų plotų praradimas dèl užliejimo ir patvenkimo, vandens gyvūnų migracijos, dauginimosi ir produktyvumo pokyčiai, upių vagų erozijos ir tvenkinių krantų abrazijos reiškiniai, kultūros paveldo objektų praradimas užliejamose teritorijose [4, 11-13]. Taigi prieš ịrengiant tvenkinị būtina ivertinti visus teigiamus (naudos) ir neigiamus (nuostolių) aspektus ir priimti sprendimą, tenkinantị darnaus vystymosi principų reikalavimus.

Lietuvoje yra 450 nuotekio reguliavimo tvenkinių, kurių plotas didesnis kaip 5 ha [14]. Šiems tvenkiniams pagal analogiją su ežerais nustatytas ir privalomas natūraliems ežerams būdingas vandens lygių kaitos intervalas [2]. Taip išspręstas la- bai svarbus tvenkinio vandens lygiu kaitos poveikis vandens gyvūnijai, augalijai, tvenkinio krantams ir požeminiams vandenims.

Lietuvos aplinkosaugos aktai [2] reguliuoja tvenkinio kaip sudetinès vandens ekosistemos dalies vandens lygių režimą, kuris nustatomas remiantis analogija su natūralių ežerų vandens lygių kaita. Tvenkinio naudojimo ir priežiūros taisyklès leidžia nežymų $(10-20 \mathrm{~cm})$ vandens lygio pokyti normalaus patvankos lygio atžvilgiu. Tokia tvenkinio vandens lygio kaita palanki aplinkai ir buvo pagrịstai pasirinkta, nes tai patvirtina natūralių Lietuvos ežerų lygių kaitos stebèjimai per 2010-2016 metus.

Ežerų vandens lygių kaitos vertinimui naudoti Lietuvos hidrometeorologinès tarnybos vandens matavimo stočių (1 lentelè) kiekvienos dienos lygių stebejjimai Tauragnuose (Tauragno ež.) ir Trakuose (Totoriškių ež.). Šių ežerų ištakose nẻra patvankos įrenginių, ir vandens lygių stebëjimo duomenys atspindi natūralų lygių kaitos procesą. Remiantis 2010-2015 m. vykdyto valstybinio upių, ežerų ir tvenkinių monitoringo rezultatais, šiuose ežeruose stebima gera ekologinè būklè [15].

Šių ežerų didžiausių ir mažiausių vandens lygių pokyčių per mėnesị (1 pav.) analizė rodo, kad

1 lentelè. Natūralių ežerų vandens lygių stebẻjimų duomenys

\begin{tabular}{|c|c|c|c|c|c|c|}
\hline \multirow{2}{*}{ Ežeras } & \multirow{2}{*}{$\begin{array}{c}\text { Vandens matavimo } \\
\text { stotis }\end{array}$} & \multirow{2}{*}{$\begin{array}{c}\text { Baseino } \\
\text { plotas, km² }\end{array}$} & \multirow{2}{*}{$\begin{array}{c}\text { Ežero plotas, } \\
\text { km² }^{2}\end{array}$} & \multirow{2}{*}{$\begin{array}{l}\text { Stebėjimy } \\
\text { laikotarpis }\end{array}$} & \multicolumn{2}{|c|}{ Vandens lygio pokytis per mėnesį, cm } \\
\hline & & & & & vidutinis & didžiausias \\
\hline Tauragnas & Tauragnai & 68,6 & 5,13 & 2010-2016 & 10,5 & 50 \\
\hline Totoriškių & Trakai & 13,7 & 0,76 & 2010-2016 & 4,6 & 12 \\
\hline
\end{tabular}

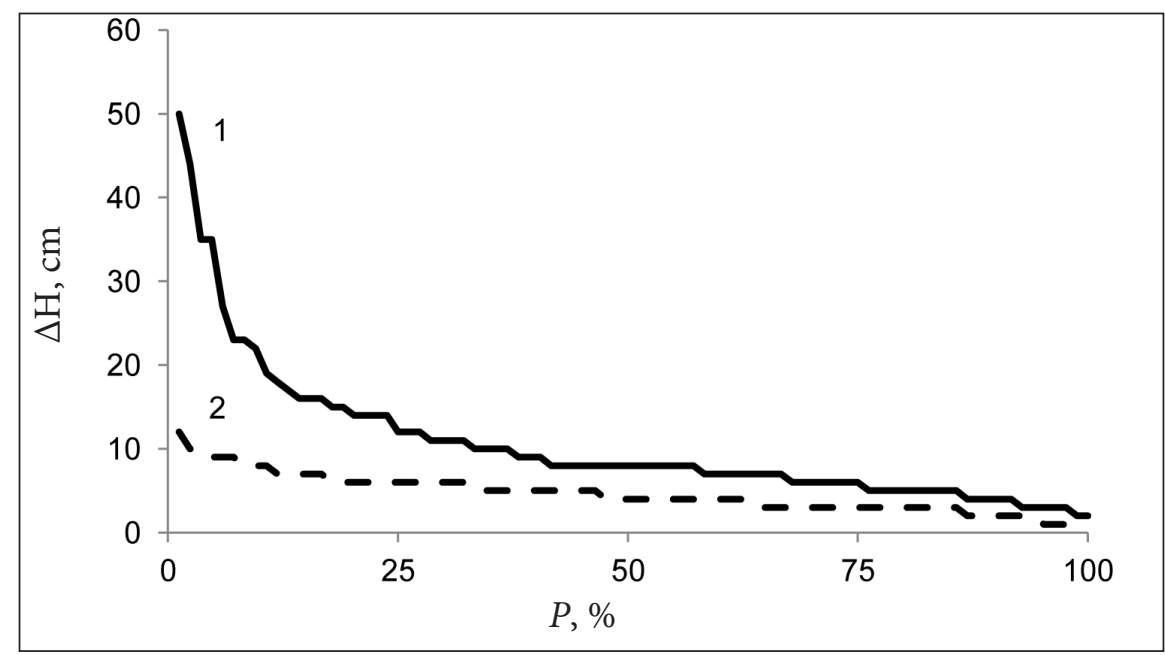

1 pav. Tauragno (1) ir Totoriškių (2) ežerų vandens lygių pokyčių per mėneș tikimybių pasiskirstymo kreivès 
Totoriškių ežere didžiausias vandens lygio pokytis buvo vos $12 \mathrm{~cm}$, o Tauragno ežere $90 \%$ atvejų neviršija $20 \mathrm{~cm}$. Tauragno ežere tik per pavasario potvyni (vasario, kovo ir balandžio mèn.) buvo pastebèti didesni kaip $20 \mathrm{~cm}$ lygio pokyčiai, tai sudaro vos $7,1 \%$ visu atvejų.

\section{EKOLOGINIO NUOTĖKIO VEIKSNIAI IR NUSTATYMO PRINCIPAI}

Daugelyje Europos valstybių gamtosaugos debitas apskaičiuojamas kaip nekintanti vidutinio metinio debito dalis arba kaip reglamentuoto dažnio minimalus upés debitas $[1,16]$. Toks gamtosauginio debito reglamentavimas priimtinas tik vienu atveju, kai projektuojant siekiama ịvertinti paviršinio vandens telkinio būklę kritinemis sąlygomis. Per tvenkinio išteklių eksploataciją nustatyti kiekvienais metais fiksuotą nekintanti gamtosaugos debitą pagal jo kritinę reikšmę nepriimtina, nes tai reikštų, kad nepriklausomai nuo vandeningumo kasmet upès ekosistema ir jos organizmai patiria stresines situacijas kritinemis sąlygomis.

Pavyzdžiui, Vokietijoje gamtosaugos debitas sudaro 0,3-0,6, o Ispanijoje, Italijoje ir Prancūzijoje - vos 0,1 vidutinio metinio debito [16]. Esminis tokio gamtosaugos debito nustatymo metodo trūkumas yra tas, kad pažeidžiama stebèta daugiametė upès debitų kaita. Dažniausiai gamtosaugos debitas siejamas su vidutiniu metiniu debitu motyvuojant tuo, kad vidutiniai debitai matuojami tiksliau už minimalius debitus, kuriems būdingi atsitiktiniai svyravimai ir didesnès nustatymo paklaidos.

Lietuvos upių gamtosaugos debito apskaičiavimo tvarkos aprašas [3] reglamentuoja vidutinio 30 parų trukmès minimalaus debito nustatymą, susiedamas ji su daugiamečio pasikartojimo tikimybe. Šiuo laikotarpiu upejje gali būti ir daug mažesni paros debitai, tačiau reikalaujama, kad gamtosauginis debitas iš tvenkinio būtų ne mažesnis už 80 arba $95 \%$ tikimybès vidutinị 30 parų minimalų debitą.

Tokia gamtosaugos debito nustatymo metodika pratęsè iki tol galiojusius statybinių normų ir taisyklių reikalavimus upès „sanitariniam debitui“ apskaičiuoti. Sąvoka „sanitarinis debitas" buvo vartojama nustatant nuleidžiamųjų (kanalizacijos) vandenų atskiedimą švariu upès vandeniu, skaičiuojant ir pagrindžiant užteršto vandens valymo lygi. Ribiniu upès vandens debitu buvo pasirinktas $95 \%$ tikimybès upès minimalaus mènesio (30 parų) debitas. Tai reiškia, kad vieną kartą per 20 metų bus ribinès nuotekų atskiedimo sąlygos, o likusius 19 metų nuotekų atskiedimo sąlygos bus palankesnès. Pritaikius tokią gamtosauginio („sanitarinio“) debito sampratą, kai kurioms nuotekị reguliuojančioms hidroelektrinèms atsirado normatyvè spraga, leidžianti kiekvienais metais per sausmetị trūkstant vandens sumažinti praleidžiamą per hidroelektrinę debitą iki gamtosaugos debito. Tuo tarpu sukauptas tvenkinyje vanduo panaudojamas energijai gaminti vieną ar kelias valandas per parą. Pagrindine tokio pulsuojančio energijos gamybos būdo priežastis - didelès ịrengtos turbinos pralaidumas, palyginti su gamtosauginiu debitu.

Reikšmingiausios dabar galiojančio gamtosaugos dokumento problemos yra šios:

1. Gamtosaugos debito nustatymo normatyvai taikomi ir hidroelektrinems, kurios neišleidžia užteršto vandens, bet keičia vandens telkinių hidrologini režimą, sukeliantị nenusistovejusị tekèjimą ir didelę debitų kaitą HE reguliuotoje upès atkarpoje.

2. Normatyvuose nereglamentuojama vandens lygio kaita gamtosaugos debito praleidimo laikotarpiu. Tai ypač pastebima, kai HE veikia paros reguliavimo režimu. Nors hidroelektrinè naudoja upès tranzitinị nuotekị (tvenkinio prietakos debitą) ir palaiko leistiną tvenkinio vandens lygio kaitą, tačiau dèl didelio HE turbinų pralaidumo sukelia potvynius upès reguliuotame ruože (didelis palyginti su gamtosaugos debitu turbinos pralaidumas staiga ijungus turbinas keleriopai padidina reguliuotos upès ruožo debitą, sukeldamas ekosistemai vandens lygio ir greičio pokyčius).

Parenkant tvenkinio žemutinio bjefo (reguliuotos upès) ekologinio nuotèkio režimą, būtina remtis šiais pagrindiniais principais:

- atsižvelgiant ị vandens gyvūnijos ir augalijos poreikius sudaryti palankias sąlygas vandens telkiniuose egzistuoti biocenozèms;

- pakankamas teritorijos ir vandens telkinių hidrologinis ištirtumas, leidžiantis objektyviai apskaičiuoti upių nuotèkio rodiklius bet kuriam upès ruožui;

- tgyvendinimo paprastumas ir suderinamumas su upių baseinų valdymo planais; 
- operatyvaus valdymo galimybè, kuri leistų ne tik realiu laiku greitai apskaičiuoti ekologinio nuotekkio parametrus, bet juos stebèti ir kontroliuoti.

Šių principų igyvendinimas įmanomas pamažu ir kryptingai plečiant vandens telkinių tyrimus ir diegiant gautus rezultatus. Ne visi minèti principai šiuo metu gali būti igyvendinti, nes nepakanka stebejjimo duomenų ir jų apibendrinimo.

Reguliuotos upès ekologinis potencialas ir su juo susijęs ekologinis nuotékis priklauso nuo gamtinių ir antropogeninių sąlygų. Gamtinių sąlygų kompleksą sudaro:

- klimatas ir jo kaita, lemiantys prietaką $\mathfrak{i}$ tvenkini, garavimo nuostolius iš tvenkinio, vandens temperatūrą;

- upés nuotèkio gamtinis sureguliavimas, priklausantis nuo vietinių fizinių geografinių sąlygų (baseino ploto, ežerų ir pelkių, miškų ir geologinès sudèties);

- vagos nuolydis, nuo kurio priklauso hidromorfologiniai rodikliai (tèkmès greitis, gylis, plotis ir vagos būklè).

Ekologinį nuotekị žemutiniame bjefe labiausiai gali paveikti ši antropogeninè veikla: hidroelektrinès darbo režimas ir negrị̌tamas vandens paèmimas.

Reguliuotų upių ekologinio nuotèkio veiksnius lemia tos pačios fizinès geografinès sąlygos, kurios formuoja upių bazini nuotèkį, bei upès išteklių naudojimo tikslai ir pobūdis. Upès bazinio nuotèkio dydis arba nuotekio gamtinio reguliavimo koeficientas $\varphi[5,12]$ priklauso nuo klimato ir nuotèkị reguliuojančių veiksnių (geologinès sudèties, baseino ploto, ežerų, miškų ir kt.). Hidrometriniai stebejimai ir atlikti tyrimai [5] leidžia koeficientą $\varphi$ nustatyti bet kuriai Lietuvos upei.

Nuotèkio reguliavimo koeficientui būdingos šios savybès:

- atspindi upių nuotekio santykinị pasiskirstymą tarp pagrindinių metų sezonų;

- kiekvienų metų nuotékio reguliavimo koeficientas nepriklauso nuo metų vandeningumo;

- gamtinį nuotèkio sureguliavimą lemia fizinès ir geografinès sąlygos;

- maža metinio nuotèkio reguliavimo koeficiento dispersija bėgant laikui [5].

Sezoninis upių nuotèkio pasiskirstymo pobūdis labai svarbus vandens ekosistemoje vykstantiems žuvų neršto, paukščiu perẻjimo ir gyvūnų migracijos procesams.

Jūros ties Taurage nuotèkio stebejjimų duomenys ( 2 pav.) patvirtina, kad ịvairaus vandeningumo metais yra toks pats upés bazinis nuotèkis. Panašǔs rezultatai gauti [5], kai koreliacijos koeficientai tarp $\varphi$ ir vandeningumo $Q$ Lietuvos upėms buvo nustatyti nuo $-0,35$ iki 0,27 . Ši savybè rodo, kad metų vandeningumas $Q$ ir nuotèkio reguliavimo koeficientas $\varphi$ yra tarpusavyje

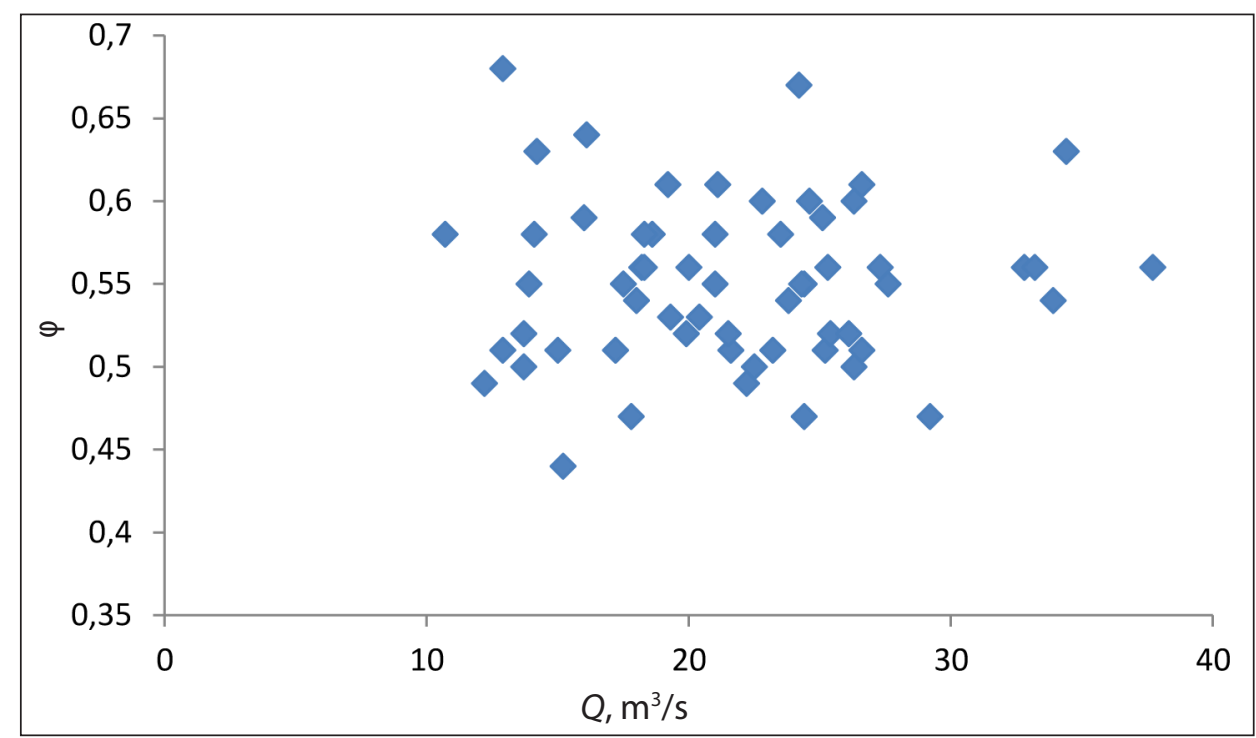

2 pav. Ryšys tarp Jūros upès metų vandeningumo $(Q)$ ir metinio nuotèkio reguliavimo koeficiento $(\varphi)$. Tauragès vandens matavimo stoties 1922-2016 m. duomenys 
nepriklausomi ir papildo vienas kitą informacija apie nuotèki.

Nuotékio reguliavimo koeficientą yra palanku naudoti, nes jis pasižymi maža dispersija bėgant laikui [5]. Tai reiškia, kad vidutinei daugiametei reikšmei pakanka trumpo nuotèkio stebejjimo laikotarpio.

\section{HIDROELEKTRINIŲ POVEIKIS NUOTĖKIO REŽIMUI REGULIUOTOSE UPĖSE}

Stebimi du reguliuotos upès nuotèkio režimai:

1. Palankus aplinkai režimas, kai užtvankos pralaidos arba hidroelektrinè praleidžia ị žemutinį bjefą prietakos debitą, laikantis tvenkiniui nustatytos vandens lygiu kaitos. Reguliuotas debitas sumažẻja dèl papildomų garavimo nuostolių nuo tvenkinio vandens paviršiaus ir negrižztamo vandens naudojimo, kuris gali sudaryti 10-20\% tvenkinio prietakos.

2. Nepalankus aplinkai režimas, kai hidroelektrine arba vandens vartotojas staiga sunaudoja per vieną arba kelias paras sukauptą tvenkinyje vandeni. Tai trumpalaikio (paros ar savaitès) nuotekio reguliavimo atvejis, kai gaminama pikinè energija. Išplètotoje elektros energetikos sistemoje toks energijos būdas kartu su vejo ar kinetinès energijos šaltiniais nebeaktualus [17, 18]. Sezoninis ar daugiametis nuotèkio reguliavimas padidina reguliuotos upès sausmečio nuotèkị [9] per pavasario potvynị sukauptu vandeniu.

Reguliuotos upès atkarpa, kurioje ypač pastebimas hidroelektrinès darbo pikinio režimo poveikis, priklauso nuo tvenkinio prietakos nuotekio santykio su gamtosaugos debitu. Kai šis santykis lygus vienetui, hidroelektrinè veikia naudodama prietakos ị tvenkinị nuotekị (tranzitinis naudojimas arba run of river režimas [4, 19]). Kai hidroelektrinè praleidžia didesnị debitą negu nustatytas gamtosauginis debitas, o prietaka ị tvenkinị yra mažesnè už turbinos debitą ir naudojamas sukauptas tvenkinyje vanduo, stebime hidroelektrinès pikinị darbo režimą. Tai vadinamasis hidropikingas [19].

Lietuvos mažųjų hidroelektrinių turbinų pralaidumo analizè (2 lentelè) rodo, kad hidroelektrinių vienos turbinos praleidžiamas debitas viršija gamtosaugos debitą, nustatytą pagal Lie- tuvoje galiojanti normatyvą [3]. Iš 96 mažųjų hidroelektrinių [20] net 43,8 \% hidroelektrinių turbinų pralaidumas šešis ir daugiau kartų viršija gamtosaugos debitą. Tai reiškia, kad šios turbinos gali gaminti energiją per sausmetị tik vandeningais ir vidutinio vandeningumo metais, kai sausmečio prietaka $\mathfrak{x}$ tvenkini yra lygi arba didesnè už turbinos debitą. Priešingu atveju, kai prietaka ị tvenkinị mažesnè, hidroelektrinè naudos tvenkinio išteklius pikinei energijai gaminti.

2 lentelè. Lietuvos mažujų hidroelektrinių pasiskirstymas pagal vienos turbinos debito santykị su gamtosaugos debitu

\begin{tabular}{c|c|c}
\hline $\begin{array}{c}\text { Hidroelektrinės turbi- } \\
\text { nos debito santykis su } \\
\text { gamtosaugos debitu }\end{array}$ & $\begin{array}{c}\text { Hidroelektrinių } \\
\text { skaičius }\end{array}$ & $\begin{array}{c}\text { Dalis (\%) bendru } \\
\text { hidroelektrinių }\end{array}$ \\
\hline$<1$ & 12 & 12,5 \\
\hline $1-5$ & 42 & 43,7 \\
\hline $6-10$ & 21 & 21,9 \\
\hline $11-20$ & 9 & 9,4 \\
\hline$>20$ & 12 & 12,5 \\
\hline
\end{tabular}

Hidropikingo poveiki reguliuotos upès ekologinei būklei švelnina šios priemonès:

- palankių aplinkai dvigubo pralaidumo reguliavimo (kreipračio ir pasukamų menčių) turbinų naudojimas;

- izvairios galios ir pralaidumo turbinų naudojimas (esant kelioms turbinoms hidroelektrinèje);

- turbinų pralaidumo ir stabdymo laiko ilginimas.

Tranzitinio upès nuotèkio (tvenkinio prietakos) per hidroelektrinę praleidimas garantuoja tiek tvenkinio vandens lygio nedidelę kaitą, tiek ekologinị nuotèkị žemutiniame bjefe.

\section{NEIŠTIRTŲ UPIỤ TVENKINIŲ PRIETAKOS IR EKOLOGINIO NUOTĖKIO NUSTATYMAS}

Ekologinio nuotekio, vertinančio biologinị vandens telkinių potencialą ir ekologinę būklę, nustatymas bet kuriai neištirtai Lietuvos upei, įmanomas priimant upès nuotékio sinchroniškumo hipotezę. Upès nuotèkio kaitą (vandeningumą bet kuriuo laiko momentu) lemia klimato veiksnių (kritulių, oro temperatūros) poveikis upių nuotèkiui, kuris pasireiškia didelèse teritorijose. 
Mažose ir vidutinèse upèse, kurių baseino plotas iki $10000 \mathrm{~km}^{2}$, turime vos po 3-5 vandens matavimo stotis. Todèl svarbu nustatyti, kokio dydžio teritorijoje galime apibendrinti vienos vandens matavimo stoties nuotèkio stebejjimų duomenis.

J. Jablonskio ir R. Janukènienès tyrimai [21] rodo, kad Lietuvoje yra šeši sinchroninio upių nuotèkio rajonai. Šiuose rajonuose gretimų upių metinio nuotèkio tarpusavio koreliacijos koeficientai viršija 0,8 . Nustatyta porinès koreliacijos koeficiento priklausomybè nuo atstumo tarp vandens matavimo stočių. Siekiant patikslinti galimybes naudojantis vienos vandens matavimo stoties stebėjimais skaičiuoti prietaką $\mathfrak{i}$ bet kuri tvenkini arba nustatyti ekologinį nuoteki hidroelektrinès žemutiniame bjefe, buvo panaudoti Lietuvos upių baseinų daugiamatès (hidrologinių, hidrografinių, vandens ūkio ir gamtosaugos rodiklių) klasifikacijos rezultatai [22], kurie leido nustatyti optimalų rajonų skaičių (7) pagal hidrologinès, landšafto ir vandens naudojimo sąlygas.

Kiekviename rajone parinkome atramines vandens matavimo stotis. İvertinant upių vandens matavimo stočių pasiskirstymą ir stebejjimų trukmę buvo parinkta 15 atraminių vandens matavimo stočių, kurių stebejjimų duomenys buvo perkelti su mažiausiomis paklaidomis (3 lentelè). Buvo apskaičiuoti šių Lietuvos upių baseinų 46 vandens matavimo stočiu metinio nuotekio tarpusavio koreliacijos ryšiai [5]. Dauguma šių ryšių (96 \%) pasižymi aukštais koreliacijos koeficientais, viršijančiais 0,8 , o 64 \% atvejų šių ryšių glaudumas vertinamas didesniais kaip 0,9 koreliacijos koeficientais. Tai rodo, kad nustatant neištirtų upių hidrologinius rodiklius ar ekologinio nuotekio dydit, galime turèti vieną atraminę vandens matavimo stotį kiekviename iš 15 Lietuvos vidutinių ir mažų upių baseinų (3 pav.). Ši atraminè vandens matavimo stotis gali pateikti upių vandeningumo informaciją realiu laiku ne tik nustatant hidroelektrinių darbo režimą mažo vandeningumo laikotarpiais, bet ir kontroliuojant hidroelektrinių darbą. Telemetriškai stebint tvenkinio vandens lygio kaitą ir ją gretinant su hidroelektrinès valandine galia, pakanka informacijos apie hidroelektrinès darbą ir jos ittaką žemutinio bjefo ekologiniam nuotèkiui. Labai svarbu, kad atkrinta būtinybe kontroliuoti hidroelektrinès darbą pagal labai netikslią žemutinio bjefo debitų kreivę mažų debitų srityje.

3 lentelè. Lietuvos upių nuotėkio baseinų sinchroniškumo tyrimų rezultatai

\begin{tabular}{|c|c|c|c|c|c|c|}
\hline $\begin{array}{l}\text { Eil. } \\
\text { Nr. }\end{array}$ & Upės baseinas & $\begin{array}{c}\text { Baseino } \\
\text { plotas, } \mathbf{k m}^{2}\end{array}$ & $\begin{array}{c}\text { Vandens } \\
\text { matavimo } \\
\text { stočių skaičius }\end{array}$ & $\begin{array}{l}\text { Mažiausia vienalaikių } \\
\text { stebëjimų trukmé, } \\
\text { metai }\end{array}$ & $\begin{array}{c}\text { Tarpusavio ryšio } \\
\text { koreliacijos } \\
\text { koeficientai }\end{array}$ & $\begin{array}{l}\text { Atraminè vandens } \\
\text { matavimo stotis }\end{array}$ \\
\hline 1. & Merkys & 3781 & 4 & 13 & $0,80-0,95$ & Puvočiai \\
\hline 2. & $\begin{array}{c}\text { Nemuno } \\
\text { vidurupio upès }\end{array}$ & 4233 & 3 & 25 & $0,80-0,86$ & Verbyliškès \\
\hline 3. & Žeimena & 2793 & 2 & 16 & 0,86 & Pabradè \\
\hline 4. & Šventoji & 6891 & 3 & 22 & $0,90-0,94$ & Ukmergè \\
\hline 5. & Nevèžis & 6140 & 3 & 22 & $0,78-0,91$ & Panevèžys \\
\hline 6. & Dubysa & 1972 & 3 & 15 & $0,92-0,95$ & Lyduvènai \\
\hline 7. & Mituva & 773 & 2 & 12 & 0,98 & Žindaičiai \\
\hline 8. & Šešupè & 4899 & 3 & 23 & $0,88-0,95$ & Kudirkos Naumiestis \\
\hline 9. & Jūra & 3994 & 4 & 21 & $0,93-0,96$ & Tauragè \\
\hline 10. & Minija & 2942 & 3 & 20 & $0,85-0,96$ & Kartena \\
\hline 11. & $\begin{array}{c}\text { Lietuvos } \\
\text { pajūrio upès }\end{array}$ & 2132 & 2 & 19 & 0,93 & Skuodas \\
\hline 12. & Venta & 5140 & 5 & 15 & $0,86-0,96$ & Papilè \\
\hline 13. & Mūša & 5297 & 4 & 18 & $0,80-0,96$ & Ustukiai \\
\hline 14. & Nemunèlis & 1892 & 3 & 15 & $0,87-0,91$ & Tabokinè \\
\hline 15. & $\begin{array}{l}\text { Dauguvos } \\
\text { intakai }\end{array}$ & 1857 & 2 & 31 & 0,94 & Guntauninkai \\
\hline
\end{tabular}




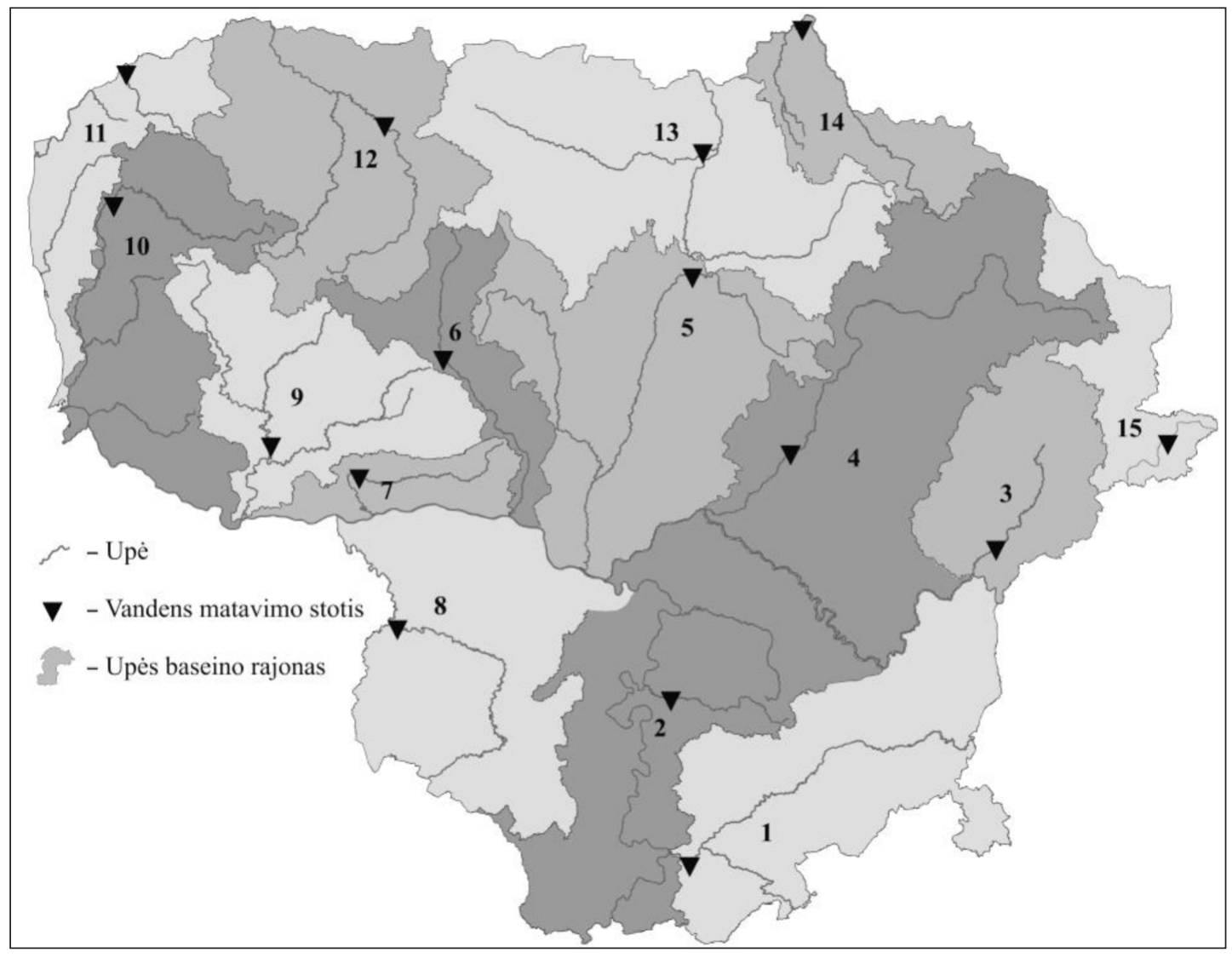

3 pav. Lietuvos vidutinių upių baseinų ir atraminių vandens matavimo stočių kartografinè schema

Dèl nepakankamo hidrologinio ištirtumo smulkūs Nemuno ir Neries intakai priskirti gretimiems upių baseinams pagal upių metinio nuotèkio kaitos sinchroniškumo kartoschemą [21].

Pagrindinių Lietuvos upių baseinų nuotèkio sinchroniškumo tyrimai patvirtino, kad prietaka $\mathfrak{i}$ tvenkinị ir reguliuotų upių ekologinis nuotekis gali būti apskaičiuoti kiekvienai neištirtai upei realiu laiku pagal atraminę vandens matavimo stoti.

\section{IŠVADOS}

Taikant visuomenès ir aplinkos darnaus vystymosi principus, tvenkinių vandens išteklių naudojimas priimtinas tik toks, kai tvenkinio vandens lygių kaita artima natūralių ežerų lygių kaitai, o žemiau tvenkinio reguliuotoje upejje stebimas vandens debitų režimas, sinchroniškas su bendra teritorijos vandeningumo kaita. Lietuvoje reglamentuota mažu ir vidutinių upių tvenkinių lygių kaita yra palanki biotai ir aplinkai bei sudaro sąlygas igyvendinti reikalavimus, keliamus apibrèžiant reguliuotos upès ekologini nuotekị.

Svarbiausias ekologinio nuotèkio veiksnys yra fizinès ir geografinès sąlygos, lemiančios upès vagos būklę, nuotèkio dydị, daugiametę kaitą ir metų nuotékio pasiskirstymą. Klimato poveikis nuotèkiui ir jo daugiametei kaitai nusako bendrą teritorijos vandeningumą. Nuotekio reguliavimo koeficientas yra svarbus rodiklis, rodantis upès sezoninio nuotèkio pasiskirstymo palankumą ekosistemoje vykstantiems procesams: žuvų nerštui, paukščių perejjimui, gyvūnų migracijai. Rengiant ekologinę upių klasifikaciją bei nustatant upių ekologinį nuotèkí, nuotèkio reguliavimo koeficientas turi būti vertinamas kartu su vandeningumu ir vagos nuolydžiu.

Pagal Lietuvoje galiojančius teisès aktus nustatytas reguliuotos upès gamtosaugos debitas keičia sausmečio debitų pasikartojimo dažnį. Tai yra pagrindinè reguliuotos upés ekosistemos stresinių situacijų priežastis, lemianti pakeisto vandens telkinio ekologinę būklę. Pagrindinès priemonès siekiant geros pakeisto vandens telkinio būklès 
yra ekologinio nuotekio žemutiniame bjefe nustatymas ir hidroelektrinių turbinų įrangos tobulinimas.

Pasiūlytas neištirtų upių ekologinio nuotèkio nustatymo metodas, paremtas upių nuotekio sinchroniškumo tyrimais ir nuotèkio ištekejjimais vienoje vandens matavimo stotyje kiekviename iš 15 pagrindinių upių baseinų. Tai paprastas ir objektyvus būdas valdyti tvenkinių vandens išteklius ir kontroliuoti hidroelektrinių darbo režimą.

Gauta 20181108 Priimta 20181220

\section{Literatūra}

1. European Commission. Guidance. Document No. 31. Ecological Flows in the Implementations of the Water Framework. Technical Report 2015-086. Luxembourg: Office for Official Publications of the European Communities, 2015.

2. Tvenkinių naudojimo ir priežiūros tipinès taisyklès LAND 2-95, patvirtintos Lietuvos Respublikos aplinkos apsaugos ministerijos $1995 \mathrm{~m}$. kovo 7 d. ịsakymu Nr. 33 (Žin., 2006, Nr. 1013915).

3. Gamtosauginio vandens debito apskaičiavimo tvarkos aprašas, patvirtintas Lietuvos Respublikos aplinkos ministro $2005 \mathrm{~m}$. liepos $29 \mathrm{~d}$. įsakymu Nr. D1-382 (Žin., 2005, Nr. 94-3508).

4. Guidance for Run-of-river Hydropower Development. Bristol: Environment Agency, 2016.

5. Gailiušis B., Jablonskis J., Kovalenkovienè M. Lietuvos upés. Hidrografija ir nuotèkis. Kaunas: Lietuvos energetikos institutas, 2001.

6. Kesminas V., Virbickas T., Stakènas S., Steponėnas A. Vokès upès ichtiofaunos apžvalga. Acta hidrobiologica Lithuanica. 2000. Vol. 11. P. 252266.

7. Vaikasas S., Palaima K., Pliūraite V. Influence of hydropower dams on the state of macroinvertebrates assemblages in the Virvyte river, Lithuania. Journal of Environmental Engineering and Landscape Management. 2013. Vol. 21(4). P. 305-315.

8. Ždankus N., Vaikasas S., Sabas G. Impact of a hydropower plant on the downstream reach of a river. Journal of Environmental Engineering and
Landscape Management. 2008. Vol. 16. P. 128134.

9. Ždankus N. Influence of hydropower plant to river flow regime. Proceedings of International Conference on Small Hydropower, May 23-25, 2001, Kaunas, Lithuania. P. 3/54-3/60.

10. Kilkus K. Lietuvos ežeru hidrografija. Vilnius: Mokslas, 1989.

11. Ždankus N., Sabas G. The influence of anthropogenic factors to Lithuanian rivers flow regime. Proceedings of the 6 th International Conference Environmental Engineering, 26-27 May, 2005, Rome, Italy. P. 515-522.

12. Skomorowski K. E., Metcalfe R. A., Finucan S. D., Jones N., Marty J., Power M. Ecosystem level assessment of environmentally based flow restrictions for maintaining ecosystem integrity: A comparison of a modified peaking vs. unaltered river. Ecohydrology. 2011. Vol. 4. P. 791-806.

13. Stromberg J. C., Beauchamp V. B., Dixon M. D., Lite S. J., Paradzick C. Importance of low-flow and high-flow characteristics to restoration of riparian vegetation along rivers in arid south-western United States. Freshwater Biology. 2007. Vol. 52. P. 651-679.

14. Gailiušis B., Kinderis Z., Lietuvininkas G., Ruplys B., Vaišnoras A. Lietuvos tvenkiniu žinynas. Vilnius: Projektų analizès institutas, 2017.

15. Nemuno upiu baseinu rajono valdymo planas. Vilnius: Aplinkos apsaugos agentūra, 2017.

16. Palau A. Integrated environmental management of current reservoirs and regulated rivers. Limnetica. 2006. Vol. 25. No. 1-2. P. 287-302.

17. Gailiušis B., Jakimavičius D., Šarauskienė D., Jurgelènaitė A. Assessment of hydrokinetic resources of small and medium-size rivers; the Lithuanian case. Baltica. 2017. Vol. 30. No. 1. P. 23-30.

18. Jakimavičius D., Gailiušis B., Šarauskienè D., Jurgelènaitè A., Meilutytè-Lukauskienè D. Assessment of the riverine hydrokinetic energy resources in Lithuania. Baltica. 2014. Vol. 27. No. 2. P. 141-150.

19. Haas N. A., O’Connor B. L., Hayse J. W., Bevelhimer M. S., Endreny T. A. Analysis of daily peaking and run-of-river operations with flow variability metrics, considering subdaily to seasonal time scales. Journal of the American Water Resources Association. 2014. Vol. 50. P. 1622-1640. 
20. Mažoji hidroenergetika. Vilnius: Lietuvos hidroenergetikų asociacija, 2017.

21. Jablonskis J., Janukènienè R. Lietuvos upių nuotékio kaita. Vilnius: Mokslas, 1978.

22. Gailiušis B. Izpolzovanie stoka rek Litovskoy SSR. Vilnius: Mokslas. 1986. 156 s.

Brunonas Gailiušis, Gintaras Adžgauskas,

Aldona Tomkevičienè,

Diana Meilutytè-Lukauskienè

\section{ASSESSMENT OF THE ECOLOGICAL FLOW OF} THE LITHUANIAN RIVERS

\section{Summary}

Reservoirs have a significant influence on the aquatic organisms of the regulated rivers, river runoff, reservoir banks, river channels, groundwater and landscape. Currently, the legislation regulates the fixed/constant environmental discharge, which satisfies only minimum needs of the aquatic ecosystem and does not depend on water abundance of the year. Such practice of the calculation of environmental discharge leaves for hydropower plant owners a possibility of hydropeaking.

In this research some aspects of the exploitation of reservoirs of small and medium rivers in Lithuania were discussed, and it is suggested to use the term of ecological flow instead of environmental discharge for regulated rivers. The most important condition for the calculation of the ecological flow is the similarity of changes of reservoir levels with the natural regime of lakes as well as the similarity of discharges of regulated rivers with the runoff of natural rivers. The inflow of unexplored rivers to the reservoir and ecological flow were estimated based on the data of water gauging stations in each of the 15 river basins of Lithuania. Therefore, improvement of the equipment of hydroelectric turbines is proposed for a good ecological condition of the regulated rivers. This allows using river runoff during the drought period in order to avoid peak regime (hydropeaking).

Keywords: ecological flow, environmental discharge, regulated rivers, reservoir, hydropeaking 